\title{
ISQUEMIA AGUDA DE LA EXTREMIDAD INFERIOR COMO POSIBLE COMPLICACION DE COVID-19.
}

\section{Este artículo está bajo una licencia de Creative Com- mons de tipo Reconocimien- - No comercial - Sin obras derivadas 4.0 International. OPEN ACCESS}

Buitrón Gabriel ${ }^{1 *}$, Briceño Cesar ${ }^{2}$, Suárez Christian ${ }^{3}$, Andrade María José ${ }^{4}$

1 Hospital General Docente de Calderón. Médico del área de Especialidades Quirúrgicas. Quito, Ecuador. 2 Hospital del día del Instituto Ecuatoriano de Seguridad Social "IESS" Sangolquí. Médico del Servicio de Cirugía Vascular. Quito, Ecuador.

3 Universidad Central del Ecuador. Facultad de Ciencias Médicas. Carrera de Medicina. Quito, Ecuador

4 Pontificia Universidad Católica del Ecuador. Facultad de Medicina. Carrera de Medicina. Quito, Ecuador

\section{ORCID ID:}

Buitrón Gabriel

orcid.org/0000-0002-5435-2242

Briceño Cesar

orcid.org/0000-0001-8583-5071

Suárez Christian

orcid.org/0000-0002-0587-7798

Andrade María José

orcid.org/0000-0003-0356-0284

* Corresponding author:

Buitrón Gabriel

E-mail: gbuitronp87@hotmail.com

Article history: Manuscript presented at the I Clinical Case Contest - Hospital Vozandes Quito, February

$27,2021$.

CARE 2017 Check List statement: The authors have real the CARE 2017 Check List and the manuscript was prepared and revised according to the CARE 2017 Checklist.

Conflict of interest: All authors declared that there are no conflicts of interest.

Financial disclosure: The authors have no financial relationships relevant to this article to disclose.

Forma de citar este artículo: Buitrón

G, Briceño C, Suárez C, Andrade MJ. ISQUEMIA AGUDA DE LA

EXTREMIDAD INFERIOR COMO POSIBLE COMPLICACION DE COVID-19. Rev Med Vozandes. 2021; 32 (1 Suppl 1): S7-S8

\section{Resumen}

Introducción: Isquemia arterial aguda en extremidades inferiores es una emergencia vascular con alto riesgo de pérdida de una extremidad y morbimortalidad asociada. Su debut en contexto de infección por virus SARS-COV2 es inusual, de la cual se desconoce su incidencia. Está documentado en las referencias mundiales, trombosis venosa superficial y profunda y trombosis arterial periférica.

Descripción del Caso: Se presenta el caso de un paciente de 69 años, con hábito tabáquico previo durante 15 años que acude con dolor agudo de miembro inferior izquierdo y ausencia de pulsos poplíteo y distales.

Los estudios complementarios de imagen demostraron ausencia de permeabilidad eje arterial izquierdo desde arteria femoral izquierda, planteándose un diagnóstico de isquemia arterial aguda de extremidad inferior izquierda. Se considera isquemia aguda amenazante marginal (Rutherford IIA) asociada a infección por SARS-COV2, por lo que se realizó embolectomía femoral y poplítea selectiva con arteriografía de control.

El paciente recupera permeabilidad de ejes arteriales en extremidad inferior izquierda y es dado de alta con anticoagulación, analgesia. Linforrea postquirúrgica de herida poplítea que cede con medidas de compresión. En seguimiento por Consulta Externa cursa con evolución favorable, sin signos de isquemia.

Conclusión: Es el primer caso reportado en la literatura médica de nuestro país de isquemia arterial aguda localizada en extremidades inferiores. El diagnóstico requiere un alto grado de sospecha clínica para su correcta identificación. El tratamiento recomendado es quirúrgico y/o farmacológico. 


\section{Abstract \\ Keywords: COVID-19, \\ Thrombosis, Peripheral artery disease, ischemia, arterial occlusion. \\ ACUTE LOWER LIMB ISCHEMIA AS A POSSIBLE COMPLICATION OF COVID-19.}

Introduction: Acute arterial ischemia in lower extremities is a vascular emergency with a high risk of limb loss and elevated morbidity and mortality associated. SARS-COV2 virus infection is usually not related to acute arterial ischemia and its incidence is unknown. World references have been documented such as superficial and deep vein thrombosis and peripheral arterial thrombosis.

Case description: We present the case of a 69-year-old patient, previous smoker for 15 years, who presented with acute pain in the left lower limb followed by absence of distal and popliteal pulses.

Complementary imaging studies demonstrated the absence of left arterial patency from the left femoral artery, raising a diagnosis of acute arterial ischemia of the left lower limb. Threatening acute marginal ischemia (Rutherford IIA) associated with SARS-COV2 infection was considered, for which selective femoral and popliteal embolectomy was performed with further control arteriography.

The patient recovers arterial patency in the left lower extremity and was discharged with anticoagulation and analgesia. Postsurgical popliteal wound developed lymphorrhea that subsides with compression measures. In follow-up, the patient has a satisfactory evolution, without signs of ischemia.

Conclusion: In the medical literature of our country, this is our first case of acute arterial ischemia located in the lower extremities.

Diagnosis requires a high degree of clinical suspicion and correct identification. Recommended treatment are surgical and/or pharmacological. 